\title{
A Study on The Students of Left Department of 'The Royal Academy (Yukyoung-gongwon)' in Late Chosen Dynasty
}

\author{
Jinkyoung Min, Hyunjung Woo, Youngmi Park, and Kwangman Choi
}

\begin{abstract}
The Royal Academy (育英公院，Yukyounggongwon) is a modern educational institution founded by the Chosen government in 1886. Since the opening the port, political situations and economic situations have changed rapidly, and the establishment of diplomatic relations with foreign governments has continued to rise. Thus, new knowledge, including foreign language skills, has begun to demand high ranking officials. To address this need, the Chosen government attempted to train young upstart bureaucrats to strengthen education on new culture through a foreign language, and to respond to the needs of the nation. Therefore, this study aims to focus on the students' career, especially among those who studied at The Royal Academy. The students of Left Department was a rookie who passed the civil service examinations at the time of the The Royal Academy. Therefore, it is necessary for the young bureaucrats to study the new educational system to prove the effectiveness of the new educational system that the Chosen Dynasty established and tried to achieve. As a result, the students of Left Department was selected as the elite in the traditional educational system of Chosen Dynasty. Through studying at The Royal Academy, they learned new knowledges, including foreign languages, with traditional Confucian knowledge. They also played an important role in the Chosen dynasty as a close aide to King Gojong. The learning of the students of Left Department was a refresher to young and talented bureaucrats. This was evidence of the Chosen Government's efforts to respond to changes in the times.
\end{abstract}

Index Terms-Modern education in Chosen Dynasty, the royal academy in Chosen Dynasty, elite education in the Late Chosen Dynasty

\section{INTRODUCTION}

'The Royal Academy (育英公院, Yukyoung-gongwon)' is a modern educational institution founded by the Chosen government in 1886. The Royal Academy has an important distinction with educational institutions established in the past. Prior to the establishment of The Royal Academy, 'Dongmun-hak (同文學)', was established to foster expert mastery of foreign languages. Compared to this, The Royal

Manuscript received October 10, 2017; revised November 23, 2017. This work was supported by the Ministry of Education of the Republic of Korea and the National Research Foundation of Korea (NRF2016S1A5A2A03927305)

Jinkyoung Min, Hyunjung Woo, Youngmi Park and Kwangman Choi are with Chungnam National University, Daejeon, Korean, Republic of Korea (e-mail: ian0735@naver.com, mobflore@cnu.ac.kr, youngmi@cnu.ac.kr, kmchoi@cnu.ac.kr).
Academy has become a little more advanced in terms of 'modern schools', the composition of the students, the curriculum, and the way in which they operate.

During the Chosen Dynasty, Schools traditionally offered Confucianism as education contents and consisted of 'local Confucian schools (鄉校, Hyanggyo)', 'Four capital schools (四部學堂, Sabuhakdang)', and 'Grand School (成均館, Sungkyunkwan)'. Apart from the education programs, the specialized educational institution maintained a separate system for training professional officials, using educational institutions or educational programs that were run independently of each ministry. In general, foreign language education was held in 'Sayeog-won (司譯院)'. However, there has been an increase in demand for foreign language classes since the opening of the port. Accordingly, the Chosen government will establish a Dongmun-hak based on a separate foreign language, which was not taught in Sayeog-won. Dongmun-hak wanted to foster a specialized official in foreign languages that could assist senior officials. These operations were similar to those of Sayeogwon. Since the establishment of Dongmun-hak, political situations and economic situations have changed rapidly, and the establishment of diplomatic relations with foreign governments has continued to rise. Thus, new knowledge, including foreign language skills, has begun to demand high ranking officials. To address this need, the Chosen government attempted to train young upstart bureaucrats to strengthen education on new culture through a foreign language, and to respond to the needs of the nation.

\section{ADVANCED RESEARCH}

A study on The Royal Academy includes G. R. Lee (1999), [1] K. M. Kim (1999), [2] B. R. Ryu (1992) [3] and S. M. Lee (2003), [4] G. Y. Kim (2010). [5] G. R. Lee (1999) and K. M. Kim (1999), B. R. Ryu (1992) mainly deal with the establishment and operation of The Royal Academy. Both S. M. Lee (2003) and G. Y. Kim (2010) conducted a follow-up to the characters expelled by The Royal Academy. Through this, The Royal Academy revealed that it was a major institution to realize the enlightenment (開化, Gaehwa) policy of King Gojong in the late Chosen Dynasty.

G. R. Lee (1999) explains that the establishment of ' The Royal Academy' was the result of a visit of Bobingsa Group (報聘使) to the United States in 1883. He also introduced 
$\ulcorner$ White Paper of The Royal Academy (育英公院謄錄, Yukyoung-gongwon Deunglok)」 to academia for the first time, and details about the operational situation and the abolishment process. [1], However, G. R. Lee (1999) says the Students and the Teachers of the academy were forced to resign their jobs, leaving the office unable to obtain the desired educational results, which eventually resulted in poor educational performance. This negative view of G. $R$. Lee (1999) is reflected in the latter half of the cohort.

K. M. Kim (1999) conducted an analysis on $\left\ulcorner_{\text {White }}\right.$ Paper of The Royal Academy $\lrcorner$. The purpose of the establishment of The Royal Academy was to encourage high-ranking officials to acquire Western knowledge such as English, allowing them to utilize for diplomacy and domestic politics. In addition, the Chosen government has a great interest in The Royal Academy and offered various benefits such as 'Examinations of The Royal Academy (育英公院應製, Yukyoung-gongwon Eungje)'. [2] However, later in the year, the students abandoned their operations due to academic laxity and mismanagement, and later changed to English schools in 1894. In conclusion, it is hard to say that the government has done its best to achieve the goal of establishing a The Royal Academy.

B. R. Ryu (1992) is as follows. The Royal Academy is a new school established by the Chosen government, and it is meaningful as the modern school led by the government. According to B. R. Ryu, there are three reasons why The Royal Academy was founded. First of all, there was an intention of China (Qing China) to interfere with Japan in the wake of the opening of the Chosen Dynasty. Second, there was an attempt by the Joseon government to restore independence through the signing of the treaty with the United States, Third power excluding Japan and China. Finally, the reform plan for modern education of Korean Reformists'(開化派, Gaehwapa) was reflected in the policy. Also, unlike the establishment of Dongmun-hak for foreign language education (English education), The Royal Academy believes that it was founded to promote national development through the introduction of Western technologies [3].

S. M. Lee (2003) evaluates 'Dongmunhak' and 'The Royal Academy' as an educational institution that was established as an interpreter for the period of enlightenment. In particular, it describes 'The Royal Academy' as a 'modern English school'. [4] However, the figures were promoted through 'Dongmunhak' and 'The Royal Academy', Through them, 'The Royal Academy' appears to be aimed at cultivating a character to conduct enlightenment policies. In other words, King Gojong (高宗) wanted to cultivate his own people who could carry out his policies through 'The Royal Academy'. However, due to the lack of coordination, 'The Royal Academy' explained that it was closed in 1894, when Japan was strengthening its intention to invade Japan.

G. Y. Kim (2010) studied ${ }^{\circledR}$ Daily Record of The Royal Academy （育英公院日錄， Yukyoung-gongwon ilok)』written by Park Gyung Won (朴經遠, 1869-?), a student at The Royal Academy. Through this, the educational situation of the The Royal Academy and the students' learning situation are revealed. [5] The reason why G. Y. Kim's research is noteworthy is as follows. It is contradictory to the assessment that the students learned that the students' learning and operation at The Royal Academy were not functioning properly, and that they had diversified the educational operation of The Royal Academy at the time. Students also study hard and emphasize the fact that students from Left Department (左院, Jwawon) backgrounds worked at the center of the Chosen Dynasty. Although further studies of students from academic backgrounds are needed, it is also possible to show the establishment of the Chosen Government through a new foreign language school established by the King Gojong .

\section{RESEARCH PURPOSE AND RESEARCH METHOD}

Most of the people who were admitted to The Royal Academy were taught in their late teens to mid-30s, and they were separated by Left Department and Right Department (右院, Uwon). Among them, Left Department were young bureaucrats who passed the civil service examinations and Right Department were young confucianist. They can check the list in existing studies and confirm their learning period. However, in the prior study, there was little interest in how they actually performed in the Chosen society. Therefore, this study aims to focus on the students' career, especially among those who studied at The Royal Academy. As mentioned earlier, students of Left Department was a rookie who passed the civil service examinations at the time of the The Royal Academy. Therefore, it is necessary for the young bureaucrats to study the new educational system to prove the effectiveness of the new educational system that the Chosen Dynasty established and tried to achieve.

For this purpose, the literature study was used as a methodology. Based on the list of personal records of ${ }^{『}$ Daily Record of The Royal Academy』, [6] we intend to utilize ${ }^{『}$ White paper of The Royal Academy』[7], ${ }^{『}$ Samabangmok (司馬榜目)』, [8] ${ }^{\circledR}$ Munguabangmok (文科榜目)』, [9] ${ }^{『}$ Resume of bureaucrat of Great Han Empire (大韓帝國官員履歷書)』, [10] ${ }^{\circledR}$ Daily Records of Royal Secritariat (承政院日記)』, [11] 『Annals of the King Gojong (高宗實錄)』. [12]

\section{LIST OF STUDENTS OF LEFT DEPARTMENT}

There are a total of 30 students who can check through ${ }^{『}$ Daily Record of The Royal Academy』. Ten of them were admitted to Right Department initially. However, they passed the civil service examination and changed his membership to the Left Department. The following table are tabulated their names (name), dates (date), admission year(a.y.), graduation year (g.y.), progress year (pg.y., from right department to left department), passing year (ps.y, low 
level/higher level).

\begin{tabular}{|c|c|c|c|c|c|c|c|c|}
\hline $\mathbb{1 0}$ & name & $\mathrm{d}$ a t e & age & $a \cdot y$ & g. $y$ & pg.y & $\begin{array}{l}\text { ps.y } \\
\text { (low }\end{array}$ & $\begin{array}{l}\text { ps.y } \\
\text { (hig }\end{array}$ \\
\hline 1 & S.K.Kim & 1861-? & 26 & 1886.08 .11 & 1893.01 & - & - & 1882 \\
\hline 2 & M.S.Yun & 1858-? & 29 & 1886.08 .11 & 1887.8 .27 & - & - & - \\
\hline 3 & P.S.Kim & 1856-? & 31 & 1886.08 .11 & 1887.8 .27 & - & - & 1880 \\
\hline 4 & W.Y.Lee & 1858-1926 & 29 & 1886.08 .11 & 1889,01.14 & - & - & 1882 \\
\hline 5 & S.W.Jung & $1856-?$ & 31 & 1886.08 .11 & 1893.01 & - & 1882 & 1883 \\
\hline 6 & Y.S.Lee & $1863-?$ & 24 & 1886.08 .11 & 1889,01.14 & - & - & 1882 \\
\hline 7 & C.H.Min & $1856-1925$ & 31 & 1886.08 .11 & 1893.01 & - & - & 1885 \\
\hline 8 & H.M.Jung & 1863-1931 & 24 & 1886.08 .11 & 1887.8.27 & - & - & 1885 \\
\hline 9 & H.H.Cho & $1858-?$ & 29 & 1886.08 .11 & 1889,01.14 & - & 1879 & 1885 \\
\hline 10 & J.K.Oh & 1868-? & 19 & 1886.08 .11 & 1889,01.14 & - & - & 1885 \\
\hline 11 & M.S.Cho & $1862-?$ & 25 & 1886.08 .11 & 1893.01 & - & 1885 & 1885 \\
\hline 12 & K.H.Kang & 1858-1922 & 29 & 1886.08 .11 & 1893.01 & - & - & 1885 \\
\hline 13 & Y.D.Min & 1863-? & 24 & 1886.08.11 & 1893.01 & - & 1879 & 1886 \\
\hline 14 & S.H.Kim & - & - & 1886.08 .11 & 1893.01 & - & - & - \\
\hline 15 & H.S.Min & 1864-? & 23 & 1886.08 .11 & 1893.01 & 1887.12 & 1885 & 1887 \\
\hline 16 & T.H.Park & $1857-?$ & 30 & 1886.08.11 & 1893.01 & 1887.12 & 1874 & 1887 \\
\hline 17 & S.J.Sim & 1861-? & 27 & 1887.09.08 & 18899.01.14 & - & 1885 & 1887 \\
\hline 18 & I.S.Jung & 1859-1938 & 29 & 1887.09.08 & 1893.01 & - & - & 1882 \\
\hline 19 & S.J.Seo & 1865-1897 & 23 & 1887.09 .08 & 1893.01 & - & 1882 & 1885 \\
\hline 20 & H.S.Kim & 1861-? & 27 & 1887.09.08 & 1889,01.14 & - & 1876 & 1879 \\
\hline 21 & H.Yun & $1856-?$ & 32 & 1887.09.08 & 1893.01 & - & - & 1885 \\
\hline 22 & S.K.Sin & 1866-? & 22 & 1887.09 .08 & 1893.01 & - & 1882 & 1886 \\
\hline 23 & S.K.Hong & 1866-? & 21 & 1886.08 .11 & 1893.01 & 1889.12 & 1885 & 1889 \\
\hline 24 & M.J.Lee & 1870-1889 & 17 & 1886.08 .11 & 1889.12 & 1888.03 & 1885 & 1888 \\
\hline 25 & S.H.Seo & 1858-1943 & 29 & 1886.08.11 & 1893.01 & 1889.06 & 1885 & 1889 \\
\hline 26 & K.W.Park & 1869-1947 & 18 & 1886.08 .11 & 1893.01 & 1892 & 1885 & 1891 \\
\hline 27 & Y.M.Min & 1863-1916 & 24 & 1886.08 .11 & 1893.01 & 1892 & - & 1891 \\
\hline 28 & H.W.Cho & $1868-?$ & 19 & 1886.08.11 & 1893.01 & 1892 & 1891 & 1891 \\
\hline 29 & D.K.Sin & 1864-? & 24 & 1887.09 .08 & 1893.01 & 1889.06 & - & 1889 \\
\hline 30 & J.W.Um & $1872-?$ & 16 & 1887.09 .08 & 1893.01 & 1892 & 1885 & 1892 \\
\hline
\end{tabular}

One out of every 30 persons was unable to verify all personal information (No.14 S. H. Kim) and traceability of the remaining 29 persons was traceable [8]-[11].

Each student had a different period of time at The Royal Academy. The period was shortened from a year to a year and a half to five years. One of them died early (No. 24 M. J. Lee), and nine of them quit midway through the academy (No.2, No.3, No.4, No.6, No.8, No.9, No.10, No.17, No.20). The remaining 20 students continued to learn new languages and knowledge until they were abolished at The Royal Academy.

The average age for 29 people who can track history is 25.24 years old. At the time of promotion to Left Department, the average age is 26.44 years old. At the entrance to the academy, there are 5 teenagers, 19 in their 20 s and 5 in their 30s. The youngest is 16 years old (No. 30 J.W.Um) and the eldest is 32 years old (No. 21 H.Yun). As eldest is only in his early $30 \mathrm{~s}$, it can clearly confirm that the Chosen government wants to organize the young officials of The Royal Academy.

\section{The EXECUTIVE EXAMINATION PASSED STATUS OF STUDENTS OF LEFT DEPARTMENT}

Among the 29 individuals who passed the test, 16 individuals who passed the low-level exams passed, [8] and 28 people passed the high level of bureaucratic examinations. [9] Only one person failed to pass the high level of bureaucratic tests (No. 2 M.S.Yun) except those who could not track down. Judging from the fact that he had already been in office before the entrance to the academy, he passed a high level of bureaucratic examination, but he seems to have been missing from the list. The average age of those who passed the high ranking exam of students of Left Department was 24.64 years old. At the time of passing the low level of bureaucratic examinations, the average age was 19.56 years old. This is quite young compared to the average age of all officials in the Chosen Dynasty.

Among the 16 applicants for the low level of bureaucracy, the Saengwon (生員) were two, and the rest of the people were Jinsa (進士). Fifteen out of 16 students passed the low level of bureaucracy before admission, and only one person passed the exam after admission (No.28 H.W.Cho). However, his acceptance of low level of bureaucracy earned him a splendid performance at the Examinations of The Royal Academy in 1889.

Ten people who passed a high level of bureaucratic examinations at The Royal Academy were admitted (No.15, No.16, No.23, No.24, No.25, No.26, No.27, No.28, No.29, No.30). They were promoted to Left Department while they were in school. They all got rewarded with good grades on the test and passed a high level of bureaucratic examination. They are constantly staring at test until they get the benefit of being able to do it at the latest stages without undergoing multiple levels of bureaucracy. Upon receiving these benefits, they passed the high level of bureaucratic examination immediately and passed away.

\section{The Histories of StUdents OF LeFt DePARTMENT}

The most important characteristic of distinguishing Left Department from Right Department is that they pass the high official bureaucracy examination. Therefore, the government's resume is very important before and after entering the Royal Academy. It is important to ascertain what role young bureaucrats educated at the academy have played in the Chosen government. That's because it shows what the Chosen government expected for education in the 
academy and how they reacted to governments' expectations. Therefore, it is necessary to look at the records of entering government offices before and after entering the academy.

We will take a closer look at the history of their careers. In particular, it looks closely at the history of the ministries, such as Seungjeong-won (承政院, King's Secretary), Crown Prince Sigang-won (世子侍講院, Educational institution of Crown Prince), Grand School (成均館, Sungkyunkwan), and foreign affairs bureau (foreign policy).

The title of "Seungji (承旨)" was the secretary of the King, and was largely promoted by the younger officers. They acted as close associates of the king. Among the students of Left Department, three were working as Seungji before entering The Royal Academy (No.1, No.2, No.21). [10]-[12] Also, there were nine students who worked as Seungji while attending the academy (No.1, No.2, No.4, No.5, No.7, No.12, No.13, No.18, No.20). [10] - [12] Also, 13 people, including some of them, became Seungji after finishing their studies at the academy and helped King Gojong (No.2, No.3, No.4, No.5, No.6, No.7, No.8, No.9, No.10, No.13, No.18, No.19, No.20). [10]-[12] In addition, there are one person who works for the Secretariat who was established in the Korean Empire (No. 15). [10]- [12]. The secretariat was a modern institution delivering orders from the king, such as Seungjeong-won. As a result, 17 out of 29 people who are identified as the result of the investigation are from King Gojong's secretary. They played a major role in the government of King Gojong. This enables King Gojong to verify the faith of the educated people in The Royal Academy.

The students of Left Department were also a close associate of King Gojong, and were also required to serve as an educator who fostered the nation's reserve officials, including the heir apparent of Chosen Dynasty. In the Chosen Dynasty, Crown Prince Sigang-won was not a noted location. However, since this is an educational institution responsible for the next king's education, the organization has excellent academic skills and relatively young caretakers. Among students of Left Department, the following are the people who worked at the Crown Prince Sigang-won. Prior to entering the Royal Academy, there were five people who worked at Sigang-won (No.3, No.5, No.6, No.18, No.20). [10]-[12] Nine people worked at Sigang-won while attending the academy (No.4, No.5, No.6, No.11, No.13, No.18, No.20, No.21, No.22). [10], [11]. [12] After finishing his studies at the academy, there were eight people who worked at Sigang-won (No.1, No.6, No.9, No.16, No.23, No.25, No.27, No.28). [10]-[12] Among the 29 members, 18 people worked as a bureaucrat in the Crown Prince Sigangwon.

Sungkyunkwan is the leading educational institution of the Chosen Dynasty, where it is designated as a top ranking official for the lowest level of bureaucratic examinations.

The head of Sungkyunkwan is 'Daesasung (大司成)', and most of the officers of Sungkyunkwan are mostly high level officials who pass high levels of bureaucracy. The fact that students of Left Department at the academy used to act as a Sungkyunkwan teacher showed that it was not related to the changes in the era of time. it can also train them to educate students of Sungkyunkwan to realize that they have attempted to combine Confucian knowledge and Western knowledge with the next generation of officials. There were no people who acted as Daesasung before entering the academy. Four people worked as Daesasung during the course of their studies (No.1, No.5, No.18, No.21), [10], [11]. [12] and eight people worked as Daesasung after completing their studies (No.4, No.6, No.7, No.10, No.11, No.13, No.20, No.25). [10]-[12] In conclusion, there are 12 students who served as Daesasung.

Many people from The Royal Academy were reclassified to educational institutions. In particular, there were many cases related to the education of the Crown Prince and the elite officials of Chosen Dynasty.

There are also many students who worked as diplomats from The Royal Academy. Their new knowledge and foreign language skills were useful in the context of the times when diplomatic issues mattered. There are seven people who have served as a Foreign Ministry official of the Ministry of Foreign Affairs and Trade (No.1, No.4, No.6, No.7, No.13, No.21, No.29). [10]-[12] In particular, they entered the diplomatic arena mainly after completing their studies at the academy. This was the culmination of the efforts of the Chosen government trying to properly exploit the knowledge and abilities acquired by the students of the Royal Academy.

\section{CONCLUSION}

All 29 students of Left Department were elite enough to pass the high level of bureaucracy before the age of 25 . They have already been educated in the Chosen Dynasty and have proved their educational achievements. Therefore, King Gojong and the Chosen government aimed at trying new education for these people could respond to the rapidly changing international situations and social changes.

Second, students of Left Department studied at least one year, and most of the people studied for more than six years. Over the course of a considerable period of time, it means that the Chosen government has invested intensive investments and management. Traditionally, Sungkyunkwan and Local Confucian School had a learning culture focusing on individual learning and reading centered on individual studies. It is natural for students to spend a considerable amount of time getting accustomed to learning at the Royal Academy, which takes place everyday after the Western style of teaching in Western countries. Nevertheless, they continued to excel until there was a massive cutbacks in student enrollment. This shows that there was a willingness of learners to respond as well as school or school operators (or government).

Third, students of Left Department worked at several agencies as bureaucratic officers, which are related to Seungjeong-won, Crown Prince Sigang-won, Sungkyunkwan, and the Foreign Ministry. In particular, there were many working records related to educational institutions. This was the result of seeking new knowledge to spread new knowledge and technologies through support for a small number of elites. Through education, the government tried to retrain the elites and the ruling elite and respond to the demands of the times. Engaging young bureaucrats as Gojong's aides in various fields reflects what 
the Chosen government has expected for these new bureaucrats.

\section{REFERENCES}

[1] G. R. Lee, "Establishment and changes of The Royal English School," The Journal of Korean Studies, no. 6, pp. 101-129, 1963.

[2] K. M. Kim, "School management and learning condition in The Royal Academy," The Korean Journal of History of Education, vol. 21, pp. 571-593, October 1999.

[3] B. R. Ryu, "A Study on The Royal Academy, The Study of Educational History" vol. 4. no. 1, pp. 121-137, May 1992.

[4] S. M. Lee, "The training of english interpreter of the Chosun Dynasty in 1880's," M.S. Thesis, Graduate School of Korea National University of Education, Chungbuk, South Korea, 2003.

[5] G. Y. Kim, "A Study on the ${ }^{\circledR}$ Daily Record of The Royal Academy』 in late Chosen Dynasty," The Study of Educational History, vol. 20, no. 2, pp. 25-82, November 2010.

[6] Yukyoung-gongwon ilok (Daily Record of The Royal Academy).

[7] Yukyoung-gongwon deunglok (Whit paper of The Royal Academy).

[8] Sama Bangmok. [Online] Available: http://people.aks.ac.kr/front/dirSer/exm/exmKingExmList.aks?classC ode=S1\&className=생 원시 \&isEQ=true\&kristalSearchArea=P; http://people.aks.ac.kr/front/dirSer/exm/exmKingExmList.aks?classC ode $=\mathrm{S} 2 \&$ className $=$ 진사시 $\& \mathrm{isEQ}=$ true $\&$ kristalSearchArea $=\mathrm{P}$

[9] Mungua Bangmok. [Online] Available: http://people.aks.ac.kr/front/dirSer/exm/exmKingExmList.aks?classC ode $=\mathrm{MN} \&$ className $=$ 문과 \&isEQ $=$ true\&kristalSearchArea $=\mathrm{P}$

[10] Daehanjekook Kwanwon Iryoukseo (Resume of bureaucrat of Great Han Empire).

[11] Sungjongwon ilgi (Daily Records of Royal Secritariat). [Online] Available: http://sjw.history.go.kr/main.do

[12] Gojong Sillok (Annals of the King Gojong). [Online] Available: http://sillok.history.go.kr/search/inspectionMonthList.do

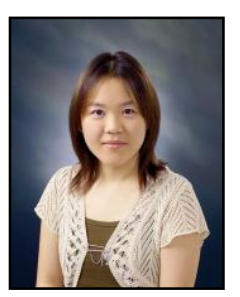

Jinkyoung Min was born in Seoul, in January 6, 1982. She graduated from the Department of Tax Accounting, Daedeok University in September 2005. She graduated from the Department of Education, Korea National Open University in February 2013. She earned her master's degree in February 2016 as a major in philosophy and history of education. She specializes as a major in education in the Joseon Dynasty.

She is currently majoring in educational history as a doctoral student at Chungnam National University Graduate School. She worked as an assistant administrator in the $\mathrm{CNU}$ educational Research, who helped publish a journal 'CNU journal of educational studies', in Daejeon city for one year from February 2016. She works as an assistant administrator in the Korean Society for History of Education, who helped publish a journal 'The Korean Journal of History of Education', in Daejeon city from January 2017. She made a poster presentation at the annual conference of the Educational Society of with 'Role of Virtue Ethics in Global citizenship education' in Daegu, Korea, in the summer of 2015. She made a poster presentation at ICEASS in Singapore in February 2016 with 'To Be Global Citizen of Korean' Yun Ch 'i-ho: Focusing on the Experience of Abroad in China. She published 'A Study of the Ssangmaedang Ahn Gyeongjik's`Jongsa-ilgi 」' papers at 'History of Education' in June 2016. She is interested in these days, research to identify 18th century educational networks using letters.

Ms. Min is also a full member of the Society for History of Education, the Korean Society for History of Education, The Korean Education Research Association.

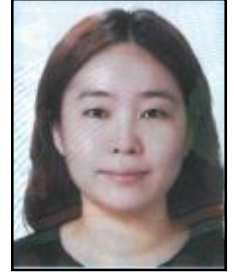

Hyunjung Woo was born on September 3, 1894 in Cheonan, South Chungcheong Province. She earned a bachelor's degree in education at Chungnam National University in February 2008, and also earned her master's degree in February of 2013 as a major in Philosophy and History of Education.

She is currently majoring in educational history as a doctoral student at Chungnam National University Graduate School. She works as an assistant administrator in the Korean Society for History of Education, who helped the administration and financial operations of the society. She recently made a presentation on the subject of 'An Analysis on the Types of official bureaucrats positions in the Late Chosen Dynasty of sayeog-won' teacher'. She also published papers such as 'An Analysis on Operation and Characteristics of Teaching Profession Course and Practice(The Journal of Korean Teacher Education, No.16 Vol.8, 2016.8.) and 'A Study on Introduction and Changes of as a subject 'Education': Focused on 18951945 Normal School(Korean Journal of Educational Research No.54 Vol.3, 2016.9). ' in 2016. She has recently been interested in the of interpreting \& translating education in the late Chosen Dynasty and the modern education.

Ms. Woo is also a full member of the Society for History of Education, the Korean Society for History of Education, The Korean Education Research Association.

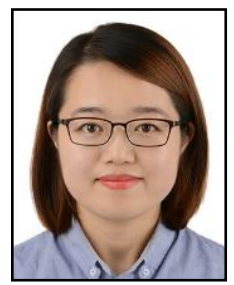

Third Youngmi Park was born in Daejeon, Republic of Korea on 13th September 1982. Park earned bachelor of arts in history in Kyunghee University, Seoul, Republic of Korea, 2007, and in education in Chonbuk National University, Jeonju, Republic of Korea, 2015.

Now, she studies history of education in master course in Department of education in Chungnam National University, Daejeon, Republic of Korea from 2015. She participated in the poster session in annual conference of Korea Educational Research Association in Daegu, Republic of Korea, 2016, the topic was 'the Role of Virtue Ethics in Global citizenship education'. She also participated in the poster session in ICEASS in Singapore, 2017, the topic was 'To be Global Citizen of Korean 'Yun Ch'iho(尹致㚖)': Focusing on the Experience of Studying Abroad in China'. Recently she is interested in higher education system in Chosen Dynasty.

Ms. Park is the member in the Korean Society for History of Education, and the Society for History of Education.

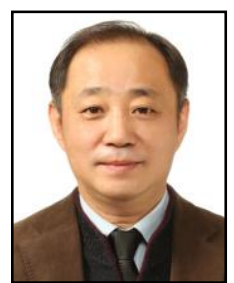

Kwangman Choi was born on April 15, 1962 in Seoul. He earned a bachelor of education from Seoul National University in 1985, and earned his master degree \& doctorate degree in education from the same graduate school in 1987, 1996. The major filed is educational history.

He served as a professor at the Chungnam Nationa University since 1999 and worked as a research commissioner at the Korea Educational Development Institute. The main publications include 'The Exploration of the History of the Late Chosen Dynasty (Daejeon: CNU Press, 2017)' and 'The Exploration of the Chosen Dynasty(Daejeon: CNU Press, 2013)'. And several other published articles related to the educational system of the Chosen Dynasty. The latest concern is the display of the late Chosen Dynasty and the lifelong learning of learning.

Prof. Choi is currently serving as a head chief of the Korean Society for History of Education, and as a board of directors of the Society for History of Education. In 2014, he won a prize for academic excellences of the Korean Society for History of Education. Both 'The Exploration of the History of the Late Chosen Dynasty (Daejeon: CNU Press, 2017)' and 'The Exploration of the Chosen Dynasty (Daejeon: CNU Press, 2013)' were selected as the Academic Library of The National Academy of Sciences, Republic of Korea. 